\title{
Infectious Bronchitis Virus: Detection and Vaccine Strain Differentiation by Semi-nested RT-PCR
}

DAuthor(s)
Okino $\mathrm{CH}^{1 a}$
Montassier MFSM ${ }^{1}$
Givisiez PEN ${ }^{1}$
Furuyama CRAG
Brentano $L^{2}$
Montassier HJ1*
1 Laboratório de Imunologia Viral,
Departamento de Patologia Veterinária,
FCAV/UNESP - Campus de Jaboticabal, SP,
Brazil
2 Centro Nacional de Pesquisa em Suínos e
Aves da EMBRAPA. Concórdia, SC, Brazil
a Graduate Student in Veterinary Medicine,
FCAV/UNESP. Jaboticabal, SP, Brasil

- Mail Address

Helio José Montassier

Departamento de Patologia Veterinária

Faculdade de Ciências Agrárias e Veterinárias

Campus de Jaboticabal - UNESP

14.884-900. Jaboticabal, SP, Brazil

Telephone: 55-16-3209-2652

Fax: $\quad 55-16-3202-4275$

E-mail: heliojm@fcav.unesp.br

\section{Keywords}

detection, differentiation, infectious bronchitis virus, semi-nested RT-PCR, vaccine strain.

\section{Acknowledgements}

The authors are grateful to Fundação de Amparo à Pesquisa no Estado de São Paulo (FAPESP - Proc. No 01/14/950-3), Conselho nacional de Desenvolvimento Científico e Tecnológico (CNPq Proc. No 477140/2003-3) and MERIAL for financial support. C. H. Okino was granted a scholarship from PIBIC-CNPq/ UNESP.

\section{ABSTRACT}

A semi-nested reverse transcription-polymerase chain reaction (Semi$\mathrm{N}-\mathrm{RT}$-PCR) was developed and used to detect the $S$ glycoprotein gene of infectious bronchitis virus (IBV) strains and to discriminate $\mathrm{H} 120$ vaccine strain from other strains. Viral RNA was extracted from the allantoic fluid of chicken embryos and from tissues of chickens experimentally infected with different strains of IBV. Amplification and identification of the viral RNA was performed using two sets of primers complementary to a region of the $S$ glycoprotein gene in the Semi-N-RT-PCR assay. The pair of primers used in the first PCR consisted of universal oligonucleotides flanking a more variable region of S1-S2 gene. The second primer pair was used in the Semi-N-RT-PCR and was comprised of one of the primers from the first universal pair together with either another universal internal oligolucleotide or a oligonucleotide sequence specific for the H120 strain of IBV. The universal primers detected all reference IBV strains and field isolates tested herein. The Semi-N-RT$P C R$ had high sensitivity and specificity, and was able to differentiate the $\mathrm{H} 120$ vaccine strain from other reference IBV strains; including M41 strain. All tissue samples collected from chickens experimentally infected with $\mathrm{H} 120$ or M41 strains were positive in the semi-nested RT-PCR using universal primers, while only the H120-infected tissue samples were amplified by the set of primers containing the H120-oligonucleotide. In conclusion, the ability of Semi-N-RT-PCR to detect distinct IBV strains and preliminarily discriminate the vaccine strain $(\mathrm{H} 120)$ closes a diagnostic gap and offers the opportunity to use comprehensive PCR procedures for the IBV diagnosis.

\section{INTRODUCTION}

The infectious bronchitis virus (IBV) is a coronavirus that causes a highly contagious disease in chickens and belongs to group III of the genus Coronavirus of the Coronaviridaefamily (Cavanagh \& Naqi, 1997). The virus predominantly replicates in the upper respiratory tract followed by viraemic spread to various organs, e.g. kidneys, reproductive tissue and lymphoid tissue (Dhinakar Raj \& Jones, 1997). Besides, replication also takes place in the intestinal tract (Dhinakar Raj \& Jones, 1996). IBV is an important pathogen characterized by a worldwide distribution and many different variants appear continuously in despite of the use of vaccines. Hence, a fast, sensitive and specific virus detection technique is of interest to the poultry industry. Nevertheless, due to high sequence variability among IBV isolates, it is difficult to develop a reverse transcription-polymerase chain reaction (RT-PCR) technique that can be reliably used to detect and differentiate all IBV isolates.

The IBV contains a genome constituted by a single stranded RNA of positive polarity, which consists of $27 \mathrm{~kb}$ and codes for three structural 
proteins: the spike glycoprotein (S), the membrane glycoprotein (M) and the nucleocapside protein (N) (Lai \& Cavanagh, 1997).

The $N$ protein of IBV is closely associated with genomic RNA and has a highly conserved amino acid sequence. Therefore, the codifying nucleotide sequences are also conserved and very little variation in the $\mathrm{N}$-gene sequence occurs between various strains of IBV. The $S$ glycoprotein is anchored in the viral envelope and is post-translationally cleaved into two proteins designated S1 and S2. In contrast to the $\mathrm{N}$ protein, the $S$ protein is very diverse in terms of both nucleotide sequence and deduced primary protein structure, especially in the upstream part of $\mathrm{S1}$, which contains also hypervariable regions (HVs) distributed along less variable and more conserved sequences of this protein (Kusters et al., 1989; Cavanagh, 1995). The most important epitopes that induce neutralizing antibodies are situated in the S protein (Kant et al., 1992). It is thus essential for the development of protective immunity (Ignjatovic \& Galli, 1994), and serotypic differences found in IBV are directly associated this protein.

Therefore, solely the detection of IBV strains by molecular diagnostic techniques can obviously be directed to the nucleoprotein gene sequence, while type differentiation can rely on identification of variable regions of S protein (Handberg et al., 1999). Alternatively to this approach, molecular diagnostic techniques can target more conserved sequences present on S1 and S2 genes of IBV. Universal primers can be designed based on these sequences and then used for the detection of IBV by RT-PCR, whereas specific primers can be designed to be complementary to the more variable regions of these genes and used in a nested or semi-nested PCR to differentiate IBV strains from different serotypes (Keeler et al., 1998; Cavanagh et al., 1999).

IBV is conventionally diagnosed by virus isolation in embryonated eggs, followed by immunological identification of isolates. Since two or three blind passages are often required for successful primary isolation of IBV, this procedure can be time-consuming. Alternatively, IBV may be isolated by inoculation in chicken tracheal organ cultures. This method is sensitive (Cook et al., 1976), but is also laborious. Additionally, IBV may be detected directly in tissue of infected birds by in situ hybridization (Collisson et al., 1990) or by immunohistochemistry (IHC) (Yagyu \& Ohta, 1990; Nakamura et al., 1991; Chen et al., 1996; Dhinakar Raj \& Jones, 1996).
RT-PCR has proved useful in detecting several RNA viruses (Cavanagh, 1993). This technique performed on IBV extracted from allantoic fluid is promising as a diagnostic tool and has been used by Jackwood et al. (1992) and by Adzhar et al. (1996). The fragments generated by RT-PCR were successfully used to differentiate IBV strains by restriction fragment length polymorphism (RFLP, Kwon et al., 1993b), sequencing (Zwaagstra et al., 1992) and hybridization (Kwon et al., 1993a). The development of RT-PCR methods using directly avian tissues is in progress (Kwon et al., 1993a; Cavanagh et al., 1997; Falcone et al., 1997; Jackwood et al., 1997; Cavanagh et al., 1999; Handberg et al., 1999), but these procedures still need to be improved. Although they do detect IBVs properly, there are some drawbacks related to differentiation between virus strains. This problem is particularly important when it is necessary to discriminate among genetically different strains that are classified within the same serotype.

Bird flocks are routinely vaccinated against IB with an attenuated live vaccine containing the strain $\mathrm{H} 120$ of IBV, which belongs to the Massachusetts serotype. This results in an additional problem concerning the discrimination of virulent field strains from the vaccine serotype using RT-PCR or even RFLP.

The present study describes the development and evaluation of a general and a strain-specific seminested RT-PCR for rapid detection and discrimination between the $\mathrm{H} 120$ vaccine strain and other IBV strains, including the strain M41, using organ samples harvested from infected birds or allantoic fluid (AF) of specific pathogen free (SPF) chicken eggs inoculated with IBV.

\section{MATERIALS AND METHODS}

\section{Viruses}

Three different reference IBV strains (H120, M41 and Arkansas 99) and one field isolate (A034) were propagated in 10-day-old specific-pathogen-free (SPF) embryonated chicken eggs. The eggs were inoculated by allantoic sac route, as described Owen et al. (1991). Virus strains were kindly provided by Empresa Brasileira de Pesquisa Agropecuária -Embrapa (Concordia, SC, Brazil).

\section{Oligonucleotides}

The oligonucleotides used to amplify gene $S$ fragments are listed in Table 1. Primers SYU (+) and SYU (-) were described by Yu et al. (2001), whereas two new oligonucleotides, VBIS- and Oligo-H120, were 
Okino $\mathrm{CH}$, Montassier MFSM, Givisiez PEN, Furuyama CRAG, Brentano L, Montassier HJ designed using Gene Runner (version 3.0.5). The antisense VBIS- oligonucleotide is complementary to a highly conserved sequence located at the beginning of the S2 gene. Oligo- $\mathrm{H} 120$ is complementary to a specific sequence of the H120 strain of IBV and was designed based on the nucleotide sequences published by Kusters et al. (1989), as well as on alignment results from Clustal X, followed by analysis using Gene Runner (version 3.0.5.).

The primers used to amplify gene $S$ fragments are listed in Table 1, whereas Figure 1 shows the annealing position of each oligonucleotide on S1 and S2. There was no similarity between the used oligonucleotides and other nucleotide sequences present in GenBank database using the BLAST tool of the National Center for Biotechnology Information (www.ncbi.nlm.nih.gov).

\section{RNA extraction}

Total viral RNA was extracted from $500 \mu$ of allantoic fluid (AF) collected from IBV-inoculated 10day-old embryonated chicken eggs using Trizol (Invitrogen, Carlsbad, CA). The extracted RNA was resuspended in $12 \mu \mathrm{l}$ of RNAse-free water, treated with diethylpyrocarbonate (DEPC).

\section{RT-PCR}

A general RT-PCR procedure was carried out according to the instructions provided with SuperScript II H-reverse transcriptase (Invitrogen). The synthesis of the cDNA first strand was performed using $5 \mu$ total viral RNA primed with random hexamers.

The following mix was used in the first PCR: $5 \mu$ of the first strand of CDNA 20 pmol of each primer (SYU+ and VBIS-), $10 \times$ PCR buffer, $0.2 \mathrm{mM}$ of each dNTP, 1.0 $\mathrm{mM} \mathrm{MgCl}$, and $2.0 \mathrm{U}$ Taq DNA polymerase (Invitrogen), and water to a final volume of $50 \mu \mathrm{l}$. Cycling conditions were as follows: one cycle of initial denaturation $\left(95^{\circ} \mathrm{C}\right.$, $8 \mathrm{~min}) ; 45$ cycles of denaturation $\left(94^{\circ} \mathrm{C}, 30 \mathrm{~s}\right)$, annealing $\left(45^{\circ} \mathrm{C}, 2 \mathrm{~min}\right)$ and extension $\left(72^{\circ} \mathrm{C}, 4.5 \mathrm{~min}\right)$; and a final extension $\left(72^{\circ} \mathrm{C}, 10 \mathrm{~min}\right)$. All reactions were performed in a thermocycler Techne Progene (Techne Incorporat, Duxford, Cambridge, UK).
Infectious Bronchitis Virus: Detection and Vaccine Strain Differentiation by Semi-nested RT-PCR

\section{Semi-nested PCR with universal oligonucleotides}

The semi-nested PCR was performed with $5 \mu$ of the cDNA produced in the RT-PCR diluted 1:20 in DEPCtreated water, $20 \mathrm{pmol}$ of each primer (SYU+ and SYU), 10 X PCR buffer, $0.2 \mathrm{mM}$ each dNTP, $1.0 \mathrm{mM}$ $\mathrm{MgCl}_{2}, 2.0 \mathrm{U}$ Taq DNA polymerase (Invitrogen) and water to a final volume of $50 \mu \mathrm{l}$. The following cycling conditions were used: initial denaturation $\left(95^{\circ} \mathrm{C}, 8 \mathrm{~min}\right)$; 25 cycles of denaturation $\left(95^{\circ} \mathrm{C}, 1 \mathrm{~min}\right)$, annealing $\left(45^{\circ} \mathrm{C}, 2 \mathrm{~min}\right)$, extension $\left(72^{\circ} \mathrm{C}, 3 \mathrm{~min}\right)$; and final extension $\left(72^{\circ} \mathrm{C}, 10 \mathrm{~min}\right)$.

\section{Semi-nested PCR with H120 strain-specific primer}

The ideal annealing temperature was previously determined using a gradient thermal cycler and reactions were prepared as follows.

The semi-nested PCR was performed with $5 \mu \mathrm{l}$ of the CDNA produced in the RT-PCR diluted 1:20 in DEPCtreated water, 20 pmol of each primer (SYU+ and OH120), 10 X PCR buffer, $0.2 \mathrm{mM}$ each dNTP, $1.0 \mathrm{mM}$ $\mathrm{MgCl}_{2}$ and $2.0 \mathrm{U}$ Taq DNA polymerase (Invitrogen), and water to a final solution of $50 \mu \mathrm{l}$, using the following conditions: initial denaturation $\left(95^{\circ} \mathrm{C}, 8 \mathrm{~min}\right)$; 25 cycles of denaturation $\left(94^{\circ} \mathrm{C}, 30 \mathrm{~s}\right)$, annealing $\left(51^{\circ} \mathrm{C}, 2 \mathrm{~min}\right)$, extension $\left(72^{\circ} \mathrm{C}, 3 \mathrm{~min}\right)$; and final extension $\left(72^{\circ} \mathrm{C}, 10 \mathrm{~min}\right)$.

\section{Experimental infection and evaluation of diagnostic sensitivity and specificity}

Three groups of SPF White Leghorn chickens were kept in positive pressure isolator units. At three weeks of age, one group was inoculated with a negative virus suspension (SPF-AF) and two groups were inoculated by ocular and intra-nasal routes with $10^{6.0}\left(\mathrm{EID}_{50} / \mathrm{ml}\right)$ of the H120 or M41 strains of IBV. Six trachea samples were collected of each group at 5 days after experimental infection. Tissue samples were submitted to virus isolation test (VI) and passed thrice in embryonated chicken eggs. Samples were considered negative or positive based on the absence or presence

\begin{tabular}{|c|c|c|c|c|}
\hline Primer & Sequence ${ }^{c}$ & \multicolumn{2}{|c|}{ Position $^{d}$} & Reference \\
\hline SYU $+{ }^{a}$ & 5'-TAYTAYTACCARAGYGCYTT-3' & $144-163 / 51$ & X04722 & YU et al. (2001) \\
\hline VBIS - b & 5'-GGACCTTATCCATACGC-3' & $1881-1865 / S 2$ & $\times 04722$ & Designed \\
\hline SYU - & 5'-TTAGADGTRWAVACAAGRTCACCATT-3' & $508-533 / 51$ & $\times 04722$ & YU et al. (2001) \\
\hline Oligo-H120 & 5'-GAAACACGTATAGAATGCTG-3' & $401-382 / 51$ & M21970 & Designed \\
\hline
\end{tabular}

${ }^{a}+=$ sense. $^{b}-=$ antisense. ${ }^{c} Y, R, D$ and $W$ represent mixtures of nucleotides $C / T, A / G, A / G / T$ and $A / T$ respectively, for degenerated primers. ${ }^{d}$ Annealing site on S1-S2 sequence, which is indicated by the accession number from GenBank. 

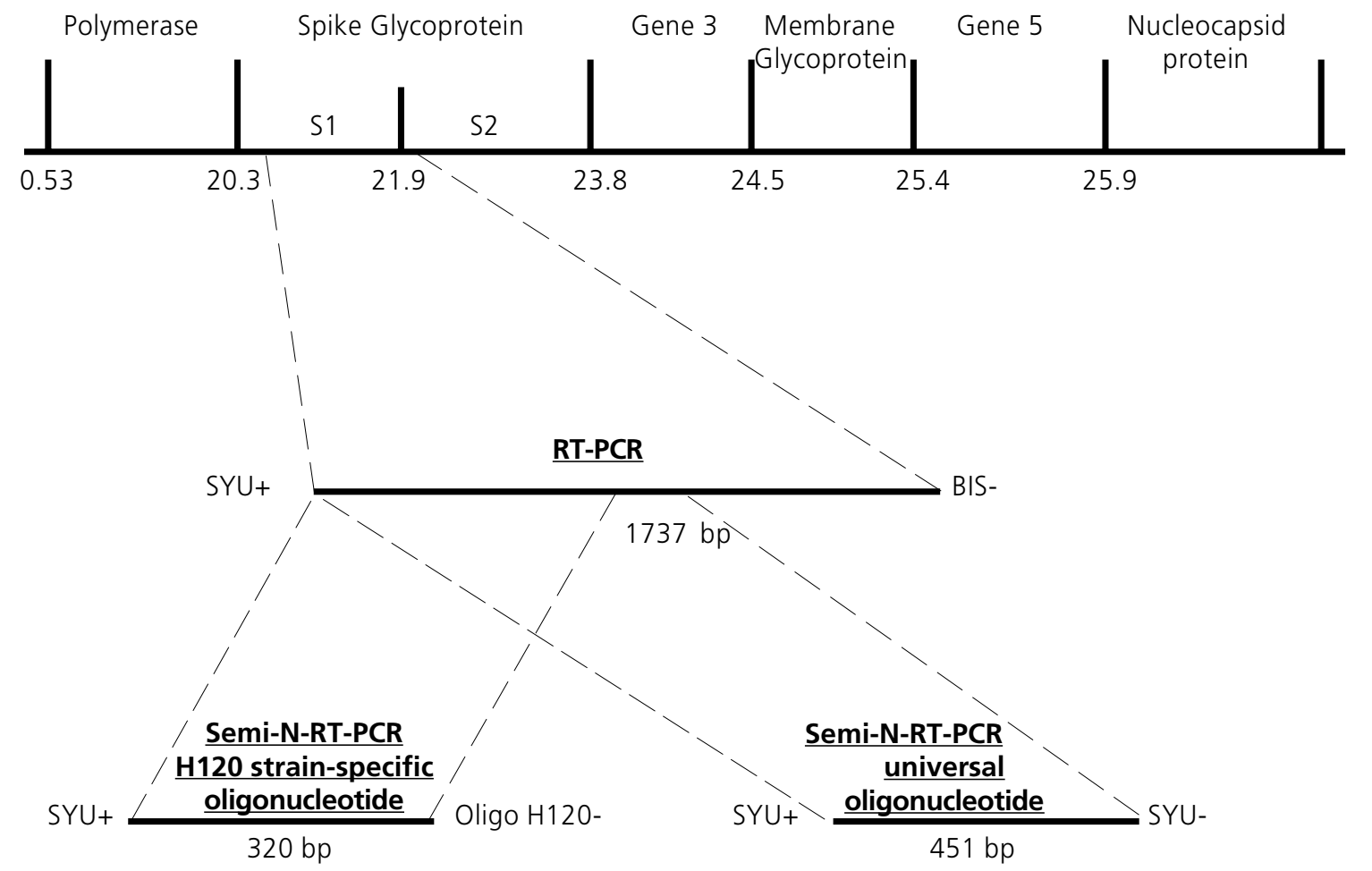

Figure 1 - Schematic representation of the plus (sense) single-stranded RNA genome of IBV. The sequences depicted represent the fragments produced in the RT-PCR using universal primers (1727bp) and in the Semi-N-RT-PCR using a universal internal primer (451bp) or a H120-specific internal primer (320bp).

of typical embryonic lesions induced by IBV, such as stunting, curling or embryo death (Gough et al., 1988).

\section{Analytical specificity}

The analytical specificity of the semi-nested RT-PCR was assessed using different antigen suspensions of homologous IBV strains (M41 and H120), a heterologous reference strain (Arkansas 99) and a heterologous field isolate (A034), as well as non-related viruses such as Newcastle disease virus (NDV/La Sota vaccine strain), infectious bursal disease virus (IBDV/ Lukert vaccine strain) and avian pneumovirus (APV/ PL21 vaccine strain).

\section{Analytical sensitivity}

A series of 10 -fold dilutions $\left(10^{0}\right.$ to $\left.10^{-10}\right)$ of RT products (CDNA) from H120 and M41 strains were used as a substrate in PCR and semi-nested PCR to evaluate the analytical sensitivity of both reactions. The amplified products of each dilution and technique were visualized by ethidium bromide staining after agarose gel electrophoresis.

\section{RESULTS}

Universal oligonucleotides evaluation in the semi-nested RT-PCR of the IBV S1 gene

Two degenerate primers (SYU+, SYU-) complementary to $\mathrm{S} 1$ regions and an anti-sense universal primer complementary to the beginning of S2 gene were used as "universal" primers in the seminested RT-PCR. This procedure allowed for a "general" amplification of the major part of $\mathrm{S} 1$ gene $(1,737 \mathrm{bp})$ in the first $P C R$, followed by the amplification of a smaller fragment of $S 1(451 \mathrm{bp})$ in the semi-nested PCR. Figure 2 shows that a fragment with the expected size (451 bp) was amplified when all four IBV strains were tested (H120, M41, Arkansas and A034).

\section{Use of a specific primer to differentiate H120 strain by semi-nested RT-PCR}

Based on differences in the nucleotide sequence, a specific primer was designed for the vaccine strain (H120). This specific primer was used together with one of the two degenerate primers (Table 1) in the semi-nested PCR of the amplified product obtained in the first PCR. An amplified product of 320 bp was 
Okino $\mathrm{CH}$, Montassier MFSM, Givisiez PEN, Furuyama CRAG, Brentano L, Montassier HJ

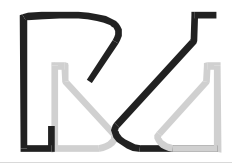

detected only for the H120 strain, differentiating this virus from the other IBV strains, including the M41strain (Figure 3).

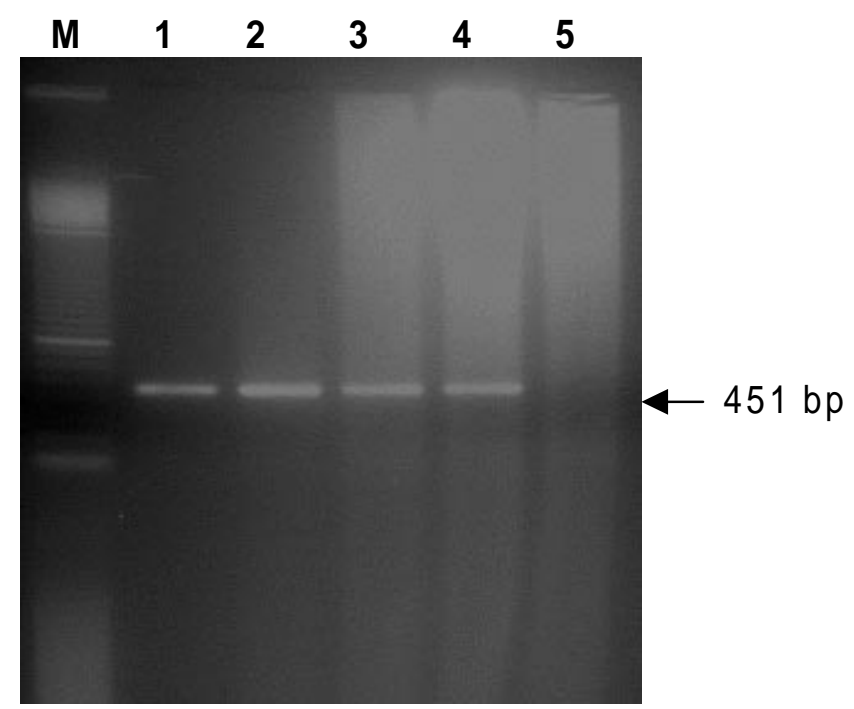

Figure 2 - Semi-N-RT-PCR. Fragment indicated with arrow (451 bp) was produced by universal oligonucleotides. Lanes: (M) Marker 100bp, (1) H120, (2) M41, (3) Arkansas, (4) A034, (5) Negative control.

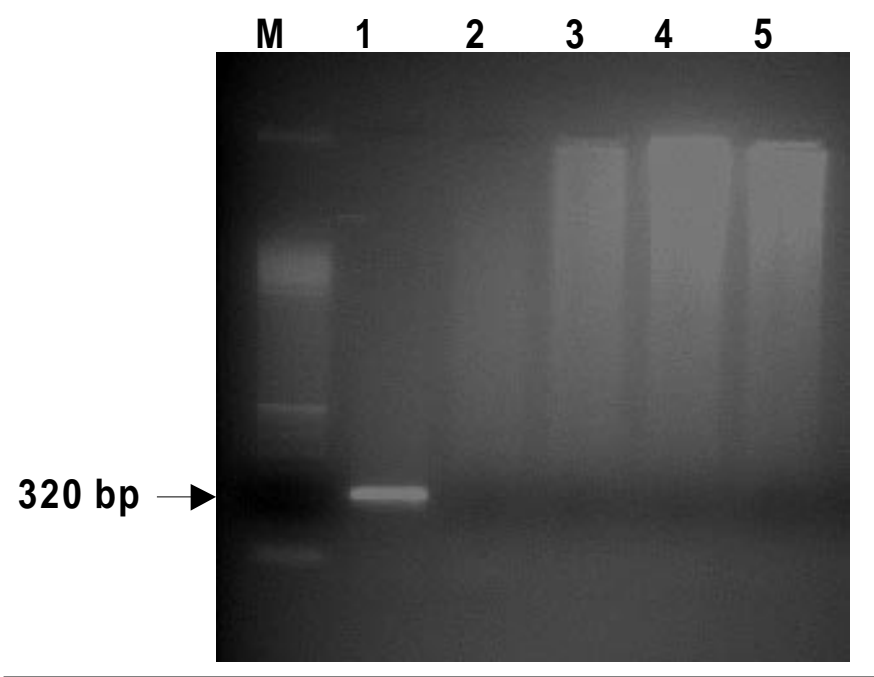

Figure 3 - Semi-N-RT-PCR. Fragment indicated with arrow (320bp) produced by a universal oligonucleotide (SYU+) and a H120 IBV strain-specific oligonucleotide. Lanes: (M) Marker 100bp, (1) H120, (2) M41, (3) Arkansas, (4) A034, (5) Negative control.

\section{Analytical Specificity}

The specificity of this procedure is also supported by the observation that only IB viruses were amplified, whilst non-related avian viral pathogens such as Newcastle, Pneumovirus and Gumboro were not detected in the PCR or semi-nested PCR techniques (Figure 4).
Infectious Bronchitis Virus: Detection and Vaccine Strain Differentiation by Semi-nested RT-PCR

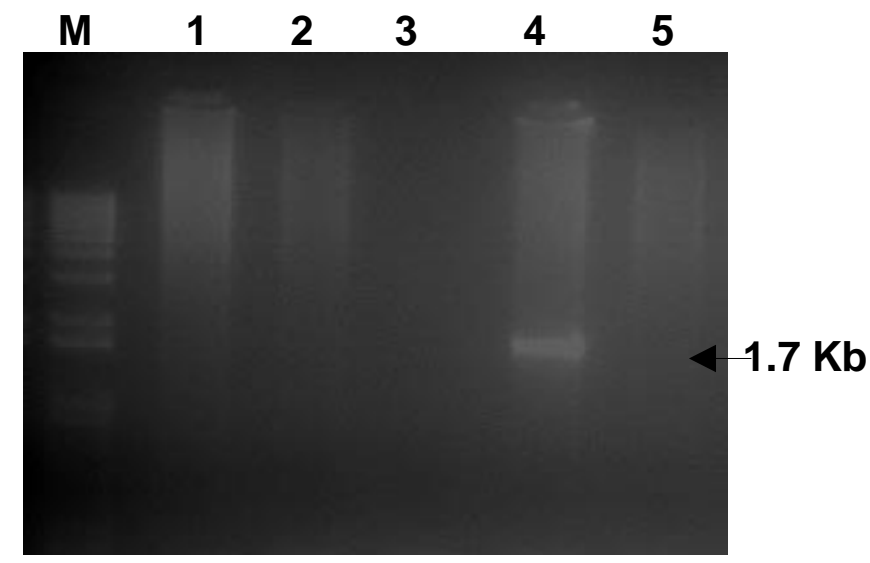

Figure 4 - Specificity analysis of RT-PCR, using universal oligonucleotides (SYU+ and VBIS-). Lanes: (M) Marker $1 \mathrm{~kb}$ plus, (1) Newcastle disease virus, (2) Gumboro disease virus, (3) Avian Pneumovirus, (4) IBV H120 strain, (5) Negative control.

\section{Analytical Sensitivity}

The sensitivity of the PCR and semi-nested PCR was evaluated by using 10 -fold dilutions of the CDNA obtained by RT from H120 and M41 strains of IBV. The detection limit of the PCR was $10^{\circ}$ and $10^{1}$ of CDNA, for $\mathrm{H} 120$ and M41 strains, respectively, which showed a band of approximately $1.7 \mathrm{~kb}$. In the semi-nested $P C R$, the detection limit of the 451-bp fragment was $10^{-4}$ and $10^{-5}$ of CDNA for $\mathrm{H} 120$ and M41, respectively (Table 2).

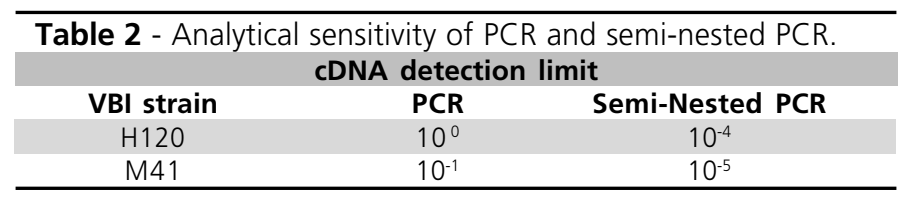

\section{Diagnostic Sensitivity and Specificity}

To evaluate the efficacy of the semi-nested RT-PCR, 12 tracheal samples collected from chickens infected with the strains H120 (6 samples) and M41 (6 samples) of IBV were tested. Tissue samples collected from $\mathrm{H} 120$ infected chickens were positive in the semi-nested RTPCR performed with either the "universal" primers or the primer specific for the H120 strain. However, tracheal samples collected from M41 strain were positive only in the semi-nested RT-PCR using "universal" primers, whereas no amplified product was detected in these samples when the semi-nested RTPCR was performed with specific H120 strain primer. IBV isolation in SPF embryonated chickens was possible from all tracheal tissue samples infected with H120 
and M41 strains. On the contrary, no IBV was detected by semi-nested RT-PCR, nor virus was isolated in tissue samples collected from the negative control birds.

\section{DISCUSSION}

The frequent emergence of new variants of IBV is one of the major obstacles to the effective control of the infection caused by this pathogen (King, 1988, Wang et al., 1994, Wang \& Tsai,1996). Relevant changes in IBV antigenicity and virulence have been reported in several countries (King, 1988, Wang \& Tsai, 1996, Wang et al., 1997, Di Fabio \& Rossini, 2000).

Molecular studies of IBV have shown that genetic and antigenic variants of this virus can emerge, mainly as a result of a few alterations or mutations in nucleotide sequences of the $\mathrm{S} 1$ gene, while the majority of the IBV genome remains unaltered (Lai \& Cavanagh, 1997). The genetic variability in the S1 subunit of the envelope spike glycoprotein gene represents an adaptive mechanism of the virus to immune selective pressures associated with intensive IBV vaccination and other management practices (Gelb et al., 1991). As a consequence, several serotypes of the virus are recognized and additional variant serotypes continue to evolve and cause disease episodes. Moreover, the vaccination of many broiler and layer flocks has been routinely made with a live attenuated vaccine against IB containing the strain H120. This strain belongs to the Massachusetts serotype and represents an additional problem for the discrimination of virulent field strains from this serotype, using RT-PCR or even RFLP techniques. Thus, accurate and rapid serotype determination has a great relevance in controlling infectious bronchitis.

As genetic variation is a quite common event among IBV isolates, the design of PCR primers to detect all IBV isolates is very difficult. Therefore, the selection of appropriate primers to be used in RT-PCR is essential for the final results in terms of sensitivity and specificity of this diagnostic technique. An additional difficulty of such approach is to conciliate, in one basic procedure of RT-PCR, the detection and identification of a given serotype or strain of IBV (Cavanagh et al., 1999).

However, comparative sequence analysis of the S1 gene of IBV revealed that there are few conserved regions flanking the variable and hypervariable regions (HVs) of this gene (Adzhar et al., 1996, Keeler et al., 1998), allowing the construction of universal primers. In the present study, primers complementary to the beginning of $\mathrm{S} 1$ gene $(\mathrm{SYU}+)$ and to the beginning of
S2 gene (VBIS-) were used in RT-PCR in order to detect a significant number of different IBV strains. A similar approach has been reported, in which a pair of universal primers was designed and successfully used in the amplification of the S1 gene of IBV by RT-PCR (Kwon et al., 1993, Adzhar et al., 1996, Keeler et al., 1998). The primers flanked the HV1 and HV2 regions of S1 gene (Keeler et al., 1998), or annealed to the beginning of S1 (positive-sense) and S2 (negativesense) (Kwon et al., 1993, Adzhar et al., 1996), in a design similar to our RT-PCR, but using different annealing sites.

Our test was designed specially for the detection of IBV, followed by the discrimination of $\mathrm{H} 120$ vaccine strain from other IBV strains, including the M41 strain, which is genetic and antigenically closely related to H120. The semi-nested RT-PCR performed with the three universal S1-S2 primers was able to detect the four IBV strains assayed here with high analytical specificity and sensitivity. Two of these strains were originally classified in the same serotype, e.g., Massachusetts, but one is attenuated and used in the live vaccine formulation ( $\mathrm{H} 120)$, whereas the other is highly virulent, particularly for the chicken respiratory tract (M41). Other two IBV strains belong to different serotypes, Arkansas 99 (serotype Arkansas) and a Brazilian field isolate (A034). Conversely, the seminested RT-PCR using a combination of the universal S1-S2 primers and the primer H120-OLIGO-generated amplified products only when the H120 strain was assessed and was able to discriminate it from the two heterologous IBV strains, as well as from the M41 strain.

Such results proved that the comparative sequence analysis of IBV S1/S2 genes have, in fact, regions that were conserved among different IBV serotypes, because three of these conserved regions were used to develop "universal" primers for amplifying IBV genomic RNA by semi-nested RT-PCR. The "universal" primers amplified all IBV strains tested. Furthermore, the "universal" primers used here were found to be IBV-specific because they did not amplify genetic material from other avian respiratory pathogens, e.g., Pneumovirus, Gumboro disease virus and Newcastle disease virus.

Although the nucleocapsid and membrane genes provide good targets for the design of "universal" primers that can be used for coronavirus identification, the co-existence of some conserved regions along with several variable regions of the $\mathrm{S} 1$ gene nucleotide sequence also permit their use for the design of both "universal" and "strain-specific" RT-PCR primers, as 
explained above and performed successfully in this study.

\section{CONCLUSION}

The method reported here was successfully used to detect IBV and efficiently discriminated the vaccine attenuated H120 strain from other IBV strains, including the M41 strain.

\section{REFERENCES}

Adzhar A, Shaw K, Briton P, Cavanagh D. Universal oligonucleotides for the detection of infectious bronchitis virus by the polymerase chain reaction. Avian Pathology 1996; 25:817-836.

Cavanagh D, Mawditt K, Britton P, Naylor CJ. Longitudinal field studies of infectious bronchitis virus and avian pneumovirus in broilers using type-specific polymerase chain reactions. Avian Pathology 1999; 28:593-605.

Cavanagh D, Mawditt K, Shaw K, Britton P, Naylor C. Towards the routine application of nucleic acid technology for avian disease diagnosis. Acta Veterinaria Hungarica 1997; 45:281-298.

Cavanagh D, Naqi S. Infectious Bronchitis. In: Calnek BW, Barnes HJ, Beard CW. Diseases of poultry. 10 th ed. Ames: lowa State University Press; 1997. p.511-526.

Cavanagh D. The Coronavirus surface glycoprotein. In: Siddel SG, editor. The Coronaviridae. New York: Plenum Press; 1995. p.73113.

Cavanagh D. Advances in avian diagnostic technology. In: X World Veterinary Poultry Association Congress; 1993; p 57-70.

Chen BY, Hosi S, Nunoya T, Itakura C. Histopathology and immunohistochemistry of renal lesions due to infectious bronchitis virus in chicks. Avian Pathology 1996; 25(2):269-283.

Collisson EW, Li J, Sneed LW, Peters ML, Wang GL. Detection of avian infectious bronchitis using in situ hybridization and recombinant DNA. Veterinary Microbiology 1990; 24:261-271.

Cook JKH, Darbyshire JH, Peters RW. The use of chicken tracheal organ cultures for isolation and assay of avian bronchitis. Archives of Virology 1976; 50:109-118.

Dhinakar Raj G, Jones RC. Infectious bronchitis virus: immunopathogenesis of infection in the chicken. Avian Pathology 1997; 26:677-706.

Dhinakar Raj G, Jones RC. Immunopathogenesis of infection in SPF chicks and commercial broiler chickens of variant infectious bronchitis virus of economic importance. Avian Pathology 1996; 25:481-501.

Di Fábio J, Rossini LI. Bronquite infeciosa das galinhas. In: Berchieri
AJr, Macari M, editores. Doença das aves. Campinas: Facta; 2000. p 293-300

Falcone E, Dqamore E, Di Trani L, Sili A, Tollis M. Rapid diagnosis of avian infectious bronchitis virus by polymerase chain reaction. Journal of Virological Methods 1997; 64:125-130.

Gelb Jr J, Wolff JB, Moran CA. Variant serotypes of infectious bronchitis virus isolated from commercial layer and broiler chickens. Avian Diseases 1991; 35:82-87.

Gough RE, Alexander DJ, Collins AS, Cox WJ. Routine virus isolation or detection in the diagnosis of diseases in birds. Avian Pathology $1988 ; 17: 893-906$.

Handberg KJ, Nielsen OL, Pedersen MW. Detection and strain differentiation of infectious bronchitis virus in tracheal tissues from experimentally infected chickens by reverse transcription-polymerase chain reaction. Comparison with an immunohistochemical technique. Avian Pathology 1999; 28:327-35.

Ignjatovic J, Galli L. The S1 glycoprotein but not the $\mathrm{N}$ and $\mathrm{M}$ proteins of avian infectious bronchitis virus induces protection in vaccinated chickens. Archives of Virology 1994; 138:117-134.

Jackwood MW, Kwon HM, Hilt DA. Infectious bronchitis virus detection in allantoic fluid using polymerase chain reaction and a DNA probe. Avian Diseases 1992; 36:403-409.

Jackwood MW, Yousef NMH, Hilt DA. Further development and use of a molecular serotype identification test for infectious bronchitis virus. Avian Diseases 1997; 41:105-110.

Kant A. Location of antigenic sites defined by neutralizing monoclonal antibodies on the S1 avian infectious bronchitis virus glycopolypeptide. Journal of General Virology 1992; 73:591-596.

Keeler CL, Reed KL, Nix WA, Gelb Jr J. Serotype identification of avian infectious bronchitis virus by RT-PCR of the peplomer (S-1) gene. Avian Diseases 1998; 42:275-84.

Kusters JG, Niesters HG, Lenstra JA, Horzinek MC, van der Zeijst BA. Phylogeny of antigenic variants of Avian Coronavirus IBV. Virology 1989; 169:217-221.

King DJ. Identification of recent infectious bronchitis virus isolated that are serologically different from current vaccine strains. Avian Diseases 1988; 32:362-364.

Kwon HM, Jackwood MW, Brown TP, Hilt DA. Polymerase chain reaction and a biotin-labeled DNA probe for detection of infectious bronchitis virus in chickens. Avian Diseases 1993a; 37:149-156.

Kwon HM, Jackwood MW, Gelb Jr JF. Differentiation of infectious bronchitis virus serotypes using polymerase chain reaction and restriction fragment length polymorphism analysis. Avian Diseases 1993b; 37:194-202.

Lai MMC, Cavanagh D. The molecular biology of coronaviruses. Advances in Virus Research 1997; 48:71-77. 
Nakamura K, Cook JKH, Oktsuki K, Huggins MB, Frazier JA. Comparative study of respiratory lesions in two chicken lines of different susceptibility infected with infectious bronchitis virus: histology, ultrastructure and immunohistochemistry. Avian Pathology 1991; 20:241-257.

Owen RL. Detection of viral antigen following exposure of oneday-old chicken to the Holland-52-strain of IBV. Avian Pathololy 1991; 20:663-673.

Wang $\mathrm{CH}$, Tsai CT. Genetic grouping for the isolates of avian infectious bronchitis viruses in Taiwan. Archives of Virology 1996; 141:1677-1688.

Wang HN, Wu QZ, Huang Y, Liu P. Isolation and identification of infectious bronchitis virus from chickens in Sichuan, China. Avian Diseases 1997; 41:279-282.

Wang L, Junker D, Hock L, Ebiary E, Collison EW. Evolutionary implications of genetic variations in the $\mathbf{S 1}$ gene of infectious bronchitis virus. Virus Research 1994; 34:327-338.

Yagyu K, Ohta S. Detection of infectious bronchitis virus antigen from experimentally infected chickens by indirect immunofluorescent assay with monoclonal antibody. Avian Diseases 1990; 37:157-169.

Yu L. Molecular epidemiology of infectious bronchitis virus isolates from China and Southeast Asia. Avian Diseases 2001; 45:205209.

Zwaagstra KA, Van der Zeijst BAM, Kusters JG. Rapid detection and identification of avian infectious bronchitis virus. Journal of Clinical Microbiology 1992; 30(1):79-84. 